\title{
Reforming the public sector in the EU: the new public
} procurement regime

\author{
by Christopher Bovis
}

The significance of the regulation of public procurement in the common market has been well documented. With a magnitude approaching 1bn Euros in supplies, works and services and representing almost 12 per cent of the EU's GDP, the potential of doing business with the public sector in an integrated market has never been greater.

\section{INTRODUCTION}

$\mathrm{P}$ ublic procurement is recognised as a key component of the economic reforms of the European Union in its attempt to become the most competitive economy in the world by 2010. The European Union has adopted a new set of rules which govern the award of contracts in the public sector as well as in utilities after a considerable amount of debate and consultation.

The new Directives which will become operational after January 31, 2006 reflect the wish of the European Union to integrate its public sector markets and bring substantial savings to the public sector. At the same time the new regime has the objective to rationalize an over-capacity ridden industry, allocate more efficiently human and capital resources, and increase the productivity and competitiveness of European firms.

\section{A THEMATIC OVERVIEW OF THE NEW PUBLIC PROCUREMENT REGIME}

Drawing on the wealth of experience from the application and implementation of previous legal regimes and the Court's jurisprudential inferences to public procurement regulation, the new Directives are set to achieve the challenging objective to fully integrate public sector purchasing in the common market and abolish any remaining non-tariff barriers.

Although the same fundamental principles underpin procurement liberalization in government and utilities sectors, the new regime maps a clear-cut dichotomy between the public sector and the utilities. Their separate regulation reveals the diametrically opposed nature of the contracting authorities/entities under these sectors and reflects on the process of transformation that utilities have been undergoing over the past decade. Their change in commercialism and competitiveness and provided for the justification of a more relaxed regime and the acceptance that utilities, in some form or another represent sui generis contracting authorities which do not need a rigorous and detailed regulation of their procurement.

The dichotomy in regulation which the new public procurement regime has established to separate public sector procurement from utilities procurement exposes an insight of current market conditions and political priorities across the European Union, as well as an indication that the main emphasis should be placed on attempts to open up the public sector.

The merger of the rules governing supplies, works and services procurement into a single legal instrument represents a successful attempt on the part of the European Union to codify supranational administrative provisions which aim to harmonize domestic legal regimes, public or private, which co-ordinate the award of public contacts. The codification, apart from the obvious benefits of legal certainty and legitimate expectation, has two important implications: legal efficiency and compliance discipline. As far as legal efficiency is concerned, the new codified Directive will speed up and streamline its implementation process by Member States, especially the new arrivals from the 2004 Accession Treaty, and provide for a one-stop shop reference point in national legal orders, augmented by the Court's vesting of direct effectiveness upon the Directive's predecessors in numerous occasions.

On the other hand, codification will enhance compliance, as it will remove any remaining uncertainties over the applicability of the previously fragmented regime and afford contracting authorities a disciplined method in dispersing their procurement functions. The main influence of the codified public sector procurement Directive can be traced in important recent case law 
developments from the European Court of Justice (for a comprehensive analysis of the public procurement case law, see Bovis, "Recent case law relating to public procurement: A beacon for the integration of public markets", 39 CMLRev, 2002). In particular, case law on the definition of contracting authorities, the use of award procedures and award criteria, and the possibility for contracting authorities to use environmental and social considerations as criteria for the award of public contracts (see for example Communication from the European Commission to the Council, the European Parliament, the Economic and Social Committee, and the Committee of the Regions, "Working together to maintain momentum" 2001 Review of the Internal Market Strategy, Brussels, 11 April 2001, $\operatorname{COM}(2001) 198$ final).

As far as the utilities procurement is concerned, the two main reasons for the introduction of a distinctive legal regime which aims at coordinating procedures for the award of contracts in the utilities sectors evolve around the relations of the state with such entities. Firstly, there is the numerous ways in which national authorities can influence the purchasing behaviour of these entities, such as participation in their capital and representation in their administrative, managerial or supervisory bodies; and secondly, the closed nature of the markets in which utilities operate, as a result of special or exclusive rights granted by the Member States, necessitates the operation of a procurement regulatory regime which ensures on the one hand compliance with the fundamental principles of the EU Treaties and on the other hand compatibility with antitrust and sector specific regulation in the utilities sectors.

\section{THE NEW CONCEPTS IN PUBLIC SECTOR PROCUREMENT}

The codified public sector Directive has introduced a series of new concepts which are the product of jurisprudential inferences and policy refining of the previous legal regimes. They intend to modernize public purchasing and align the procurement of government and its agencies with that of utilities which operate in a more commercially oriented environment.

\subsection{Eligibility of bodies governed by public law to tender}

The new public sector Directive clearly accepts that entities which are covered by its rules can participate in the award of public contracts alongside private sector undertakings. Member States should ensure that the participation of a body governed by public law as a tenderer in a procedure for the award of a public contract does not cause any distortion of competition in relation to private tenderers. The eligibility of bodies governed by public law to participate in tendering procedures has been influenced by case law (see case C-94/99, ARGE Gewässerschutzt $\quad V$ Bundesministerium für Land-und Forstwirtschaft, para 30, judgment of 7 December 2000, where the Court stated that ruled that directly or indirectly subsidized tenders by the state or other contracting authorities or even by the contracting authority itself can be legitimately part of the evaluation process). There is a protection mechanism built in Article 55(e) of the public sector Directive, which specifies that in case of abnormally law tenders, the contracting authority may reject those tenders, if it establishes that the tenderer is the recipient of state aid which may have been granted illegally. The onus to prove the legitimacy of the state aid rests with the tenderer.

\subsection{Joint and Centralized procurement}

The public sector Directive aims at introducing a regime where procurement can benefit from scale economies and streamlining planning, operation and delivery. In the light of the diversity of public procurement contracts in Member States, contracting authorities have been given the freedom to make provision for contracts for the design and execution of work to be awarded jointly. The decision to award contracts jointly must be determined by qualitative and economic criteria, which may be defined by national law. According to Article 1(10) of the public sector Directive, a central purchasing body is a contracting authority which: (i) acquires supplies and/or services intended for contracting authorities, or (ii) awards public contracts or concludes framework agreements for works, supplies or services intended for contracting authorities.

\subsection{Official list of contractors}

The public sector Directive provides for a central system of certification of private and public organizations for the purposes of providing evidence of financial and economic standing, as well as levels of technical capacity in public procurement selection and qualification procedures. Such systems must be mutually recognized by all Member States, and registration of entities in official lists of contractors, suppliers or service providers is influenced by the Court's case law, where an economic operator belonging to a group claims the economic, financial or technical capabilities of other companies in the same group in support of its application for registration (see case C-76/81, SA Transporoute et Travaux v Minister of Public Works, [1982] ECR 457; case C-27/86, Constructions et Enterprises Indusrtielles SA (CEI) $v$ Association Intercommunale pour les Autoroutes des Ardennes; case C-28/86, Ing Bellini \& Co. SpA v Regie de Betiments; case C-29/86, Ing Bellini \& Co SpAv Belgian State, [1987] ECR 3347; case C-89/92, Ballast Nedam Groep NV V Belgische Staat, [1994] 2 CMLR; case C-5/97, Ballast Nedam Groep NV V Belgische Staat, judgment of December 18, 1997; case C-176/98, Holst Italia v Comune di Cagliari, judgment of December 2, 1999).

Member States may determine the level of requirements to be met for such registrations and the period of their validity, in particular requirements for joint and several liability where an operator relies on the financial standing of another company in the same group. 


\subsection{The competitive dialogue}

The competitive dialogue is the most publicized change brought about by the new public procurement regime. Its inception is attributed to three reasons: (i) the inability of open or restricted procedures to facilitate the award of complex public contracts, including concessions and public-private partnerships, (ii) the exceptional nature of negotiated procedures without prior advertisement and (iii) the restrictive interpretation of the grounds for using negotiated procedures with prior advertisement.

Article 29 of the public sector Directive establishes the competitive dialogue as an award procedure, alongside open, restricted and negotiated procedures. The competitive dialogue must be used exceptionally in cases of particularly complex contracts, where the use of the open or restricted procedures will not allow the award of the contract, and the use of negotiated procedures cannot be justified. A public contract is considered to be particularly complex where the contracting authorities are not able to define in an objective manner the technical specifications which are required to pursue the project, or they are not able to specify the legal or financial make-up of a project.

\subsection{Framework procurement}

The new public sector Directive has for the first time introduced framework procurement to the public sector contracting authorities. According to Article 1(5) of the public sector Directive, a framework agreement is an agreement between one or more contracting authorities and one or more economic operators, the purpose of which is to establish the terms and conditions of public contracts to be awarded during a given period, in particular with regard to price and, where appropriate, the quantity of supplies, works or services envisaged.

\subsection{Electronic procurement}

The rapid expansion of electronic purchasing systems in private sector procurement and the continuous development of electronic purchasing techniques have made an impact with the public sector Directive. Electronic procurement can contribute in increasing competition and streamlining public purchasing, particularly in cases where repetitive purchasing allows efficiencies to be achieved both in time and in financial terms.

\subsubsection{Dynamic purchasing systems}

Article 1(6) of the public sector Directive provides for the establishment of dynamic purchasing systems. A dynamic purchasing system is an electronic process which allows contracting authorities to utilize techniques available to the private sector in order to procure supplies or services of repetitive nature. Any economic operator which submits an indicative tender in accordance with the specification and meets the selection criteria should be allowed to join such a system. This purchasing technique allows contracting authorities, through the establishment of a pre-selected list of tenderers, to have a particularly broad range of tenders as a result of the electronic facilities available, and to ensure, in principle, optimum use of public funds through broad competition.

\subsubsection{Electronic auctions}

According to Article 1.7 of the public sector Directive an electronic auction is a repetitive process involving an electronic device for the presentation of new prices which are revised downwards, or new values concerning certain elements of tenders. The presentation of such financial information occurs after an initial full evaluation of the tenders, enabling them to be ranked using automatic evaluation methods.

\subsection{The award criteria and the introduction of policies in public procurement}

\subsubsection{Contractual performance and public procurement}

The new public sector Directives and the new utilities Directives remain silent over the possibility of expressly authorizing social or environmental consideration as part of the award criteria of public contracts. Although the draft Directives, at the insistence of the European Parliament, contained specific provisions relevant to workforce matters as part of the award criteria, such provisions were omitted from the final text. The Commission has adopted a myopic view that considerations related to contractual performance cannot be used as criterion for the award of the contract. The Court had the opportunity to correct the Commission's interpretation and point to the right direction of its judgments, where a condition relating to the employment of long-term unemployed persons or the protection of the environment can legitimately constitute a criterion for the award of the contract (see case 31/87, Gebroeders Beentjes $v$ The Netherlands [1989] ECR 4365 at para 14; case C-225/98, Commission v French Republic, (Nord-Pas-de-Calais) [2000] ECR 7445), at para 52; case C-513/99, Concordia Bus Filandia v Helsingin Kaupunki et HKL-Bussiliikenne, [2002] ECR 7213, at para 31). However, the new public procurement regime has failed to adopt previous jurisprudential inferences and clarify the position of contacting authorities over the legitimacy of pursuing socio-economic and environmental policies through public procurement (for a detailed analysis of the ordo-liberal versus the neo-classical approach in public procurement regulation, see Bovis, "Public Procurement and the Internal Market of the $21^{\text {st }}$ Century: Economic Exercise versus Policy Choice", Chapter 17 in EU Law for the $21^{\text {st }}$ Century: Rethinking the New Legal Order, op cit).

Examples of conditions relevant to contractual performance in public contracts may include requirements to recruit long-term job-seekers or to implement training measures for the unemployed or young persons, to comply 
in substance with the provisions of the International Labour Organization (ILO) Conventions, assuming that such provisions have not been implemented in national law, and to recruit more handicapped persons than are required under national legislation.

\subsubsection{Social considerations}

In Beentjes (case 31/87, Gebroeders Beentjes op cit), the Court ruled that social policy considerations and in particular measures aiming at the combating of long term unemployment could only be part of the award criteria of public contracts, especially in cases where the most economically advantageous offer is selected. The Court accepted that the latter award criterion contains features that are not exhaustively defined in the Directives, therefore there is discretion conferred on contracting authorities to specify what would the most economically advantageous offer for them. However, contracting authorities cannot refer to such measures as a selection criterion and disqualify candidates, which could not meet the relevant requirements. The selection of tenderers is a process, which is based on an exhaustive list of technical and financial requirements expressly stipulated in the relevant Directives and the insertion of contract compliance as a selection and qualification requirement would be considered ultra vires.

The Court held that a contractual condition relating to the employment of long term unemployed persons is compatible with the public procurement Directives, if it has no direct or indirect discriminatory effect on tenders from other Member States. Furthermore, such a contractual condition must be mentioned in the tender notice (Bellini, case 28/86, [1987] ECR 3347). Rejection of a tenderer on the grounds of its inability to employ longterm unemployed persons has no relation to its suitability to perform the contract based on its economic and financial standing and its technical knowledge and ability. The Court maintained that measures relating to employment could be utilised as a feature of the award criteria, only when they are part of a contractual obligation of the public contract in question and on condition that they do not run contrary to the fundamental principles of the Treaty. The significance of that qualification has revealed the Court's potential stance over the issue of contract compliance in public procurement.

In Nord-pas-de-Calais (case C-225/98, Commission v French Republic, [2000] ECR 7445), the Court also considered whether a condition linked to a local project to combat unemployment could be considered as an award criterion of the relevant contract. The Court held that the most economically advantageous offer does not preclude the possibility for contracting authorities to use as a criterion a condition linked to the campaign against unemployment, provided that condition is consistent with all the fundamental principles of Community law, in particular the principles of non-discrimination, the right of establishment and the freedom to provide services (see Beentjes, para 29). Furthermore, even if such a condition does not contravene substantive acquis communautaire provisions, it must comply with all the procedural rules laid down in the public procurement framework and in particular the rules on advertising (See, to that effect, paragraph 31 of Nord-Pas-de-Calais, where the Court stipulated that an award criterion linked to the campaign against unemployment must be expressly mentioned in the contract notice so that contractors may become aware of its existence). The Court therefore accepted the employment considerations as an award criterion which is part of the most economically advantageous offer, provided it is consistent with the fundamental principles of Community law, in particular the principle of nondiscrimination and it is advertised in the contract notice.

\subsubsection{Environmental considerations}

In Concordia (case C-513/99, Concordia Bus Filandia v Helsingin Kaupunki et HKL-Bussiliikenne, [2002] ECR 7213), the Court was asked inter alia whether environmental considerations such as low emissions and noise levels of vehicles could be included amongst the factors of the most economically advantageous criterion, in order to promote certain types of vehicles that meet or exceed certain emission and noise levels. Advocate-General Mischo in his opinion delivered on December 13, 2001 followed the Beentjes principle and established that contracting authorities are free to determine the factors under which the most economically advantageous offer is to be assessed. Therefore, environmental considerations could be part of the award criteria, provided that they do not discriminate over alternative offers, as well as that they have been clearly publicized in the tender or contract documents.

However, the inclusion of such factors in the award criteria should not prevent alternative offers that satisfy the contract specifications being taken into consideration by contracting authorities. Clearly the Advocate General wanted to exclude any possibility of environmental considerations being part of selection criteria or disguised as technical specifications, capable of discriminating against tenderees that could not meet them. The Court held that criteria relating to the environment, in order to be permissible as additional criteria under the most economically advantageous offer, must satisfy a number of conditions; namely they must be objective, universally applicable, strictly relevant to the contract in question, and clearly contribute an economic advantage to the contracting authority (see the analysis of the Advocate General Mischo in his opinion of Concordia, paras 77 -123).

Under Article 6 of the EU Treaty, environmental protection requirements are to be integrated into the definition and implementation of the Community policies and activities referred to in Article 3 of the EU Treaty, in particular with a view to promoting sustainable development. The public sector Directive clarifies how 
contracting authorities may contribute to the protection of the environment and the promotion of sustainable development, whilst ensuring the fairness and competition in the award of public contracts. Article 50 of the public sector Directive deals with Environmental management standards. It provides that contracting authorities may require the production of certificates drawn up by independent bodies attesting the compliance of the economic operator with certain environmental management standards, they must refer to the Community Eco-Management and Audit Scheme (EMAS) or to environmental management standards based on the relevant European or international standards certified by bodies conforming to Community law or the relevant European or international standards concerning certification. Contracting authorities must recognize equivalent certificates from bodies established in other Member States. They must also accept other evidence of equivalent environmental management measures from economic operators.

\subsection{Procurement and probity}

The award of public contracts to economic operators who have participated in a criminal organization or who have been found guilty of corruption or of fraud to the detriment of the financial interests of the European Communities, or of money laundering, should be avoided. Where appropriate, the contracting authorities should ask candidates or tenderers to supply relevant documents and, where they have doubts concerning the personal situation of a candidate or tenderer, they may seek the cooperation of the competent authorities of the Member State concerned. The exclusion of such economic operators should take place as soon as the contracting authority has knowledge of a judgment concerning such offences rendered in accordance with national law that has the force of res judicata. If national law contains provisions to this effect, non-compliance with environmental legislation or legislation on unlawful agreements in public contracts which has been the subject of a final judgment or a decision having equivalent effect may be considered an offence concerning the professional conduct of the economic operator concerned or grave misconduct. Non-observance of national provisions implementing Council Directives 2000/78 and 76/207 concerning equal treatment of workers, which has been the subject of a final judgment or a decision having equivalent effect may be considered an offence concerning the professional conduct of the economic operator concerned or grave misconduct.

Article 45 of the public sector Directive deals with the personal situation of the candidate or tenderer. It provides that any candidate or tenderer who has been the subject of a conviction by final judgment of which the contracting authority is aware for one or more of the reasons listed below must be excluded from participation in a public contract: (a) participation in a criminal organization, as defined in Article 2(1) of Council Joint Action 98/733/JHA (See OJ L $351,29.12 .1998$, p 1), (b) corruption, as defined in Article 3 of the Council Act of 26 May 1997 (See OJ C 195, 25.6.1997, p.1) and Article 3(1) of Council Joint Action 98/742/JHA (See OJ L 358, 31.12.1998, p 2) respectively; (c) fraud within the meaning of Article 1 of the Convention relating to the protection of the financial interests of the European Communities (See OJ C 316, 27.11.1995, p 48); (d) money laundering, as defined in Article 1 of Council Directive 91/308 on prevention of the use of the financial system for the purpose of money laundering (see OJ L 166, 28.6.1991, p 77, Directive as amended by Directive 2001/97/EC of the European Parliament and of the Council of December 4, 2001 (OJ L 344, 28.12.2001, p 76)).

\section{THE NEW CONCEPTS IN UTILITIES PROCUREMENT}

\subsection{Remit and extent of coverage}

As a result of the liberalization process in public utilities across the European Union and the introduction of sectorspecific regulation covering the operational interface of such entities, the regulation of their purchasing practices no longer requires the rigidity and disciplined structure of that of public sector authorities. Utilities procurement has undergone a dramatic restructuring with effects varying from the relaxation of the competitive tendering regime to the total disengagement of the public procurement rules in industries that operate under competitive conditions, especially in the telecommunications and water sectors. The new utilities procurement Directive does not regard telecommunication utilities as contracting entities, since the sector has been subjected to competitive forces adequate enough to ensure its commercial character operation. Conversely, the postal sector which was previously excluded from procurement regulation is now covered, but not until January 1, 2009 in order to allow sufficient time for transitional measures aiming at the liberalisation of postal services sector of Member States. For a definition of postal activities in Member States, it is necessary to take into account the definitions of Directive 97/67/EC on common rules for the development of the internal market of Community postal services and the improvement of quality of service (See OJ L 15, 21.1.1998, as last amended by Regulation 1882/2003, OJ L 284, 31.10.2003).

The new concepts of new utilities Directive 2004/17 embrace the links of the state with utilities through special or exclusive rights and the notion of affiliated undertakings as a potential subject of utilities procurement coverage. Finally, the new regime introduces grounds for exemption for entities operating in competitive markets. 


\subsection{Special or exclusive rights in the utilities}

For the purposes of the new utilities Directive and in accordance with Article 2(3), "special or exclusive rights" mean rights granted by a competent authority of a Member State by way of any legislative, regulatory or administrative provision the effect of which is to limit the exercise of activities defined in Articles 3-7 to one or more entities, and which substantially affects the ability of other entities to carry out such activity. The activities covering special or exclusive rights embrace the following utilities sectors: Gas, heat and electricity, water, postal services, transport services, exploration for, or extraction of, oil, gas, coal or other solid fuels, as well as ports and airports

The new utilities Directive provides for a more restrictive definition of the notion of special or exclusive rights than its predecessor. The consequence of the definition is depicted in three ways: firstly, the availability of a procedure for the expropriation or use of property and the ability of an entity to place network equipment on, under or over a public highway for the purpose of constructing networks or port or airport facilities, do not automatically constitute exclusive or special rights within the meaning of the Directive; secondly a special or exclusive right does not exist merely due to the fact that an entity supplies drinking water, electricity, gas or heat to a network which is itself operated by an entity enjoying special or exclusive rights granted by a competent authority of a Member State; and thirdly, rights granted by Member State through acts of concession, to a limited number of undertakings on the basis of objective, proportionate and non-discriminatory criteria that allow any interested party fulfilling those criteria to enjoy those rights are not considered special or exclusive rights.

The practical implication of the definition of special or exclusive rights under the new utilities Directive is the non-applicability of the regime to the entities that do not meet the conditions but are still covered under the existing regime. The influence of the Court's jurisprudence in the restrictive application of special or exclusive rights is evident. The Court's approach in the British Telecommunications case does not allow the application of the sector-specific definition of leased (licensed) lines in the telecommunications sector to the respective utilities procurement definition of special or exclusive right. In that case the Court ruled that special or exclusive rights under the Leased Lines Directive (EC Directive 92/44, OJ 1992 , L 165/27) did not exist as a result of the licenses conferred by Member States to entities.

The situation could be more complicated as entities compete for such special or exclusive rights such as concessions or public-private partnerships on the basis of objective, proportionate and non-discriminatory criteria which can restrict market access to other undertakings and by definition limit the number of interested parties. The analogous application of the British Telecommunications judgment is dubious, as the Court remained silent over such scenario. The Commission however has indicated that where Member States do not enjoy discretion in the conferral of special or exclusive rights, by definition they cannot detrimentally influence the procurement behaviour of the recipient of such rights and as a consequence the utilities procurement regime need not to apply (See European Commission, "Explanatory memorandum of the proposal for the Directive co-coordinating the procurement procedures of entities operating in the water, energy and transport sectors”, COM (2000) 276 fin).

\subsection{Affiliated undertakings}

Interestingly, the new utilities regime also excludes from its remit contracts awarded to affiliated undertakings. Article 23 of the new utilities Directive excludes contracts awarded by a contracting entity to an affiliated undertaking, or by a joint venture, formed exclusively by a number of contracting entities for the purpose of carrying out activities which are covered by the utilities Directive to an undertaking which is affiliated with one of these contracting entities.

Under the new utilities procurement regime, the term affiliated undertaking means any undertaking the annual accounts of which are consolidated with those of the contracting entity in accordance with the requirements of the Seventh Council Directive 83/349 on consolidated accounts (See OJ L 193, 18.7.1983, p 1, as last amended by Directive 2001/65/EC (OJ L 283, 27.10.2001, p 28). In cases of entities which are not subject to that Directive, affiliated undertaking means any undertaking over which the contracting entity may exercise, directly or indirectly, a dominant influence within the meaning of Article 2(1)(b), or any undertaking over which the contracting entity may exercise a dominant influence by virtue of ownership, financial participation, or the rules which govern it.

\subsection{Competitive markets in utilities}

Privatized utilities could be, in principle, excluded from the procurement rules when a genuinely competitive regime within the relevant market structure would rule out purchasing patterns based on non-economic considerations. The new utilities Directive should not apply to markets where the participants pursue an activity which is directly exposed to competition on markets to which access is not limited within the relevant Member State. The new utilities Directive has therefore introduced a procedure, applicable to all sectors covered by its provisions that will enable the effects of current or future liberalization and competitiveness to be taken into account.

Article 30 of the new utilities Directive provides for the procedure for establishing whether a given activity of a utility entity is directly exposed to competition. The question of whether an activity is directly exposed to competition shall be decided on the basis of criteria that 
are in conformity with the Treaty provisions on competition, such as the characteristics of the goods or services concerned, the existence of alternative goods or services, the prices and the actual or potential presence of more than one supplier of the goods or services in question. Where access to a given market does not result from the implementation of appropriate Community legislation, it should be demonstrated that such access is uninhibited de jure and de facto.

When a Member State considers that access to the relevant market activity is uninhibited, it must notify the Commission and provide all relevant facts, and in particular of any law, regulation, administrative provision or agreements, where appropriate together with the position adopted by an independent national authority that is competent in relation to the regulation of the activity concerned. The Commission can issue a Decision which verifies that the relevant activity is provided in a competitive environment. Such verification is also presumed if the Commission has not adopted a Decision concerning the inapplicability of the utilities Directive within a certain period.

The disengagement of the utilities procurement regime as a result of the operation of the relevant entities in competitive markets by virtue of Article 30 of the new utilities Directive does not apply to the WTO Government Procurement Agreement. This represents a legal lacuna as the procedural flexibility envisaged in the European procurement regulatory regime does not cover entities covered under the GPA. Rectification of the problem would require amendment to the GPA with the conferral of concessions and reciprocal access rights to the GPA signatories.

\section{PROCUREMENT AND WTO}

The European public procurement regime has influenced to a large extent the WTO in its attempts to liberalize the public sector of its members/signatories. The principles of the European regime have been transplanted to the Government Procurement Agreement (GPA) and they epitomize a global benchmark for the award of public contracts.

The regulation of public procurement reflects on two opposite dynamics: one of a community-wide orientation and one of national priorities. These dynamics give public procurement a dimension of an economic exercise and a dimension of an exercise in policy choice respectively.

Future litigation will be extremely important in understanding the thrust of the new regime. The role of the European Court of Justice has been instrumental in shaping many of the newly introduced concepts and in the future will be invaluable in interpreting the new public procurement Directives.

\section{CONCLUDING REMARKS}

The new regime introduces a set of innovations that will make the rules more flexible, more implementable at national level and finally more enforceable. The new Public Procurement Directives evolve around three themes: simplification, modernization and flexibility.

\section{Simplification}

Under simplification, we have been promised two sets of rules (instead of four previously): one for the public sector (supplies, services and works) and one for the utilities (entities in the water, telecoms, transport, energy and post sectors). The objective of simplification has been met to a large extent. The new public sector Directive represents a notable example of legal codification which will result in increased efficiency and legal certainty.

\section{Modernisation}

Under modernization, we have been promised the introduction of a new award procedure called "competitive dialogue", which will enable the public sector to award complex projects such as public private partnerships and trans-European networks more effectively. Also, we will see the use of "framework procurement", where arrangements with a number of contractors, suppliers and service providers will last for a number of years and the public sector will have the discretion to pick a given partner from the framework list. This will bring the public sector closer to a seamless supply chain management. Finally, the new regime will introduce fully-fledged e-procurement and the use of information technology, in an attempt to process the logistics of public sector purchasing faster and more efficiently.

The objective of modernization is partly met, mainly as a result of the enormity of the newly introduced concepts. The ability of bodies governed by public law to tender for public contracts along private undertakings is a significant development. The use of framework procurement could assist in bringing the public sector closer to a seamless supply chain management. The introduction of electronic procurement and the use of information technology in public purchasing could process the logistics of public sector purchasing faster and more efficiently. However, the introduction of the competitive dialogue to facilitate the award complex projects such as public private partnerships and trans-European networks leaves many practical questions over its nature and conduct unanswered. This represents the biggest problem for the new regime.

The exceptional nature of the competitive dialogue and its hierarchy with other award procedures (the wording of the public sector Directive puts the procedure at a par with the negotiated procedures with prior advertisement); the discretion of contracting authorities to initiate the procedure (who is to determine the nature of a particularly complex contract and the inability of the contracting 
authorities to draw precise specifications and the contact's financial and legal make-up); the internal structure and conduct of the procedure (the confusion surrounding the different stages pre-tender and post tender); the response of the private sector (the predictably very high costs in participating); the degree of competition achieved (there is great potential for post tender negotiations); and finally the overall value for money results (in many instances the completive dialogue is less flexible than the negotiated procedures) are pertinent questions that have not been addressed by the new public procurement regime.

\section{Flexibility}

Finally, under flexibility, we will see the relaxation of the competitive tendering regime and the disengagement of the public procurement rules in industries that operate under competitive conditions, especially in the utilities (telecoms and water sectors).

The objective of flexibility is the surprise element of the new regulatory package. The relaxation of the competitive tendering regime and the disengagement of the public procurement rules in industries that operate under competitive conditions in the utilities sectors indicate future legal and regulatory blueprints.

However, a rather disappointing feature of the new regime is the lack of clarity over the potential use of socioeconomic and environmental considerations as part of the award criteria. Contrary to the European Court of Justice case law where the promotion of employment of the protection of the environment have been regarded as legitimate award criteria for public contracts, the new Directives do not confer the much needed flexibility in this matter to contracting authorities. (C)

Christopher Bovis

Professor of Law and Jean Monnet Chair in European and Business Law, Lancashire Law School; Visiting Senior Research Fellow, IALS, University of London.

\section{SALS Events}

Thursday 6 October, $6 \mathrm{pm}$

\section{Sponsored by Tottel Publishing Ltd DAVID DI MAMBRO}

Barrister, Lamb Chambers

Grounds of appeal

Thursday 20 October, $6 \mathrm{pm}$

\section{SARAH YOUNG}

Legal and Research Unit,

Asylum and Immigration Tribunal

The new Asylum and Immigration Tribunal

Thursday 27 October, 6pm

\section{ANN ABRAHAM}

Parliamentary \& Health Service Ombudsman

(Title to be confirmed)

\section{Thursday 10 November at $6 \mathrm{pm}$}

\section{SALS 2005 Annual Lecture

LORD JUSTICE THOMAS

Senior Presiding Judge, England \& Wales

(Title to be confirmed)

\section{Thursday 24 November}

Afternoon seminar in association with Elsevier Publishing

Understanding identity cards

(Details to be confirmed)

\section{Thursday 15 December at $6 \mathrm{pm}$}

\section{ANNE OWERS}

HM Chief Inspector of Prisons for

England \& Wales

(Title to be confirmed)

Thursday 12 January 2006

Afternoon seminar in association with Watson Burton, solicitors, Newcastle upon Tyne

(Details to be confirmed)

Venue: Marriott Newcastle Hotel, Gosforth Park.

This is a draft programme, and the calendar of events will be updated on the SALS website (http://ials.sas.ac.uk/ SALS/calendar.htm).

Booking is requested for all events, which will take place at the Institute of Advanced Legal Studies, 17 Russell Square, London WC1 unless otherwise stated. CPD accreditation with the Law Society and the General Counsel of the Bar is provided with most of our events. Those requiring CPD accreditation must register on arrival.

Please contact Sue Rogers at the SALS office (tel: 0207862 5865; email: sals@sas.ac.uk) for further information. 